\title{
Increased rates of vaccination among healthcare workers through cause-directed solutions: a state hospital example
}

\author{
Nedene yönelik çözümlerle artan aşılanma oranları: ikinci basamak \\ hastane örneği
}

Zehra KARACAER ${ }^{1}$, Hüsrev DiKTAŞ²

\section{ABSTRACT}

Objective: It was observed in our hospital in the 2013-2014 period that the need existed for the education and motivation of the staff about seasonal flu vaccine (SFV) and hepatitis B virus (HBV) vaccinations. This study was performed to evaluate the success obtained with the solution to the problems related to immunization that were previously uncovered in our hospital.

Methods: Data of this study were retrospectively collected from the 2015 and 2016 records of the Infection Control Committee (ICC). During the mentioned period, the ICC performed educational activities regarding the objective, benefits, adverse effects and risk groups of SFV and HBV vaccinations and screening tests, including face-to-face interviews, if necessary. Motivational interviews were conducted with staff who were afraid of the injection. After these activities, serolologic tests for HBV and hepatitis $\mathrm{C}$ virus (HCV) were carried out on personnel. HBV-sensitive staff were administered a triple vaccine, and their antibody reponses were monitored. A 2015-2016 SFV was administered. Participants' age, gender, occupation, department of work, HBV serology outcomes, screening test and reasons for not desiring vaccination with SFV were recorded. The data of the

\section{ÖZET}

Amaç: Aynı hastanede daha önce yapılan bir çalıșmada, 2013-2014 sezonunda personelin mevsimsel grip aşısı (MGA) ve hepatit $B$ virüsü (HBV) așısı konusunda eğitim ve motivasyona ihtiyacı olduğu saptanmıștır. Gerekli eğitici faaliyetlerden sonra yeniden değerlendirme yapılması hedeflenmiștir. Bu çalıșma ile hastanede bağıșıklama konusundaki sorunların çözümünde elde edilen bașarının değerlendirilmesi amaçlanmıștır.

Yöntem: Bu çalıșma, Enfeksiyon Kontrol Komites (EKK)'nin 01.01.2015 - 01.05.2016 tarihleri arasındaki kayıtları kullanılarak retrospektif olarak yapılmıștır. Hastanemizde sözü edilen dönemde, EKK tarafından MGA ve HBV așilaması ile tarama testlerinin amacı, yararları, yan etkileri, risk grupları gibi konularda toplu eğitimler verilmiștir. Gerekli görülen hallerde bireysel yüz yüze görüșme șeklinde eğitim faaliyetleri uygulanmıștır. Enjeksiyondan korkan personelle motive edici görüșmeler yapılmıştır. Bu aktivitelerin sonunda personelin $\mathrm{HBV}$ ve hepatit $\mathrm{C}$ virüsü $(\mathrm{HCV})$ için serolojik tarama testleri yapılmıștır. HBV’ye duyarlı personele üçlü așı takvimine uygun olarak așılama yapılmıș ve antikor yanıtları takip edilmiștir. Personele

${ }^{1} G u l h a n e$ Training and Research Hospital, Department of Infectious Diseases and Clinical Microbiology, Ankara 
study were transferred to SPSS IBM 22.0 statistical software, and a $\mathrm{p}<0.05$ level was considered statistically significant.

Results: The level of participation in the study was calculated as $84.3 \%$. The median age of the personnel was 30 (21-61) years, with 137 (54.2\%) being women. A total of 198 (78.3\%) staff underwent the investigations asked. Thirty-five $(17.7 \%)$ of the participants were found to be HBV sensitive, 148 (74.7\%) vaccinated and 15 (7.6\%) natural immunized. The median value was found to be $787.62 \mathrm{IU} / \mathrm{mL}(10.86-1000 \mathrm{IU} / \mathrm{mL})$ in the participants with positive hepatitis B surface antibody identified. Of the sensitive personnel, 32 (91.4\%) were vaccinited for $\mathrm{HBV}$, and reponse to vaccination occurred in all of them. In $55(21.7 \%)$ personnel who rejected being screened, the most common reason for not desiring investigations was determined to be "having no time" (47.3\%). Thirtysix (14.2\%) participants were administered SFV, and the most common reason for not having SFV was reported as 'having no time'.

Conclusion: In this study, it was found that the rates of SFV vaccination slightly increased, while HBV vaccination targets were substantially achieved with the necessary personal education and motivating activities performed. Besides, it was determined that personnel may participate in vaccination with a large proportion if awareness is raised through screening investigations, and educational activities could be effective for increasing the rates of vaccination.

Key Words: healthcare personnel, vaccination, hepatitis $B$ virus, seasonal flu vaccine
2015-2016 sezonunda MGA yapılmıștır. Personelin yaș, cinsiyet, meslek, çalıștığı birim, HBV seroloji sonuçları, tarama testi ve MGA yaptırmak istememe nedenleri kaydedilmiștir. Çalıșmanın verileri, SPSS IBM 22,0 (SPSS Inc, Chicago, IL) istatistik programına aktarılarak, istatistiksel açıdan $p<0,05$ düzeyi anlamlı olarak kabul edilmiștir.

Bulgular: Çalıșmaya katılım oranı \%84,3 olarak saptanmıștır. Personelin yaș ortancası 30 yıl (21-61 yıl) hesaplanmıștır. Çalıșmaya katılanların 137 (\%54,2)'si kadındır. Personelden 198 (\%78,3)'i istenen tetkikleri yaptırmıștır. Bunların 35 (\%17,7)'inin HBV'ye duyarlı, $148(\% 74,7)$ 'inin așıl, $15(\% 7,6)$ 'inin doğal bağıșık olduğu saptanmıștır. Hepatit B antikoru (Anti-HBs) pozitif saptanan hastalarda ortancası 787,62 IU/mL (10,86-1000 $\mathrm{IU} / \mathrm{mL}$ ) bulunmuștur. Duyarlı personelin $32(\% 91,4)$ 'sine HBV așısı yapılmıș, hepsinde așı yanıtı oluștuğu gözlenmiștir. Tarama testlerini yaptırmak istemeyen 55 $(\% 21,7)$ personelin öncelikli tetkik yaptırmama nedeni zamansızlık $(\% 47,3)$ olarak saptanmıștır. Personelin 36 (\%14,2)'sı MGA yaptırmıștır. MGA yaptırmamanın da öncelikli nedeni "zamansızlık” olarak bildirilmiștir.

Sonuç: Bu çalıșmada, gerekli bireysel eğitimler ve motive edici faaliyetlerle MGA așılanma oranları bir miktar yükselmiș, HBV așılama oranı hedeflerine ise büyük oranda ulașılmıștır. Ayrıca, tarama tetkikleri ile farkındalık sağlandığında, personelin așılanmaya büyük oranda katılabileceği, eğitim faaliyetlerinin așılanma oranlarında etkili olabileceği belirlenmiștir.

Anahtar Kelimeler: sağlık personeli, așılama, hepatit B virüsü, mevsimsel grip așısı

\section{INTRODUCTION}

According to a 2010 report of the European Centre for Disease Prevention and Control (ECDC), our country is one of the European countries with the highest prevalence of the hepatitis $B$ virus (HBV). Healthcare personnel are at high risk for HBV. It is estimated that 304.000 healthcare workers are injured with a sharp object which has been infected with HBV at least once in Europe every year (1).

According to the 'Extended Immunization Program' notice issued in our country, all healthcare 
personnel and students of medical faculties, dentistry faculties and vocational health high schools who have contacts with patients and their excreta have been included in the scope of the vacination program (2).

Besides HBV, healthcare personnel are recommended to have seasonal flu vaccine (SFV) (3). However, during the H1N1 pandemic seen in our country and around the world in 2009, an important part of both health staff and the rest of the community preferred personal measures, such as washing hands and staying away from crowded environments, and avoided being vaccinated $(4,5)$.

In a study, investigating the effects of hospital policies on SFV rates, the highest rate of vaccination was found to be in the hospitals with encouraging and facilitating activities (6). Meanwhile, the higest level of HBV vaccines was achieved when healthcare personnel accepted having vaccinations as a result of education together with free vaccine supplies (7).

The objective of this study is to evaluate the success achieved in the solution to the problems related to immunization that were previously determined in our hospital (8). Within this context, the personnel's screening tests, the HBV and SFV vaccination rates and the reasons for avoiding being vaccinated were evaluated.

\section{MATERIAL and METHOD}

Data of this study were retrospectively collected from the 2015 and 2016 records of the Infection Control Committee (ICC). The hospital staff were informed about the study and their consents were received.

During the mentioned period, the ICC performed educational activities regarding the objective, benefits, adverse effects and risk groups of SFV and $\mathrm{HBV}$ vaccinations and screening tests, including face-to-face interviews, if necessary. Motivational interviews were conducted with staff who were afraid of the injection.
As educational activities, seminars were held on SFV and HBV. In addition, small groups were briefed on the same topic for staff who could not attend the seminars. Visual materials such as brochures and posters were left in the staff recreation rooms. We tried to persuade the staff who were afraid of the needle by making individual conversation at rest time. We also accompanied him/her during injection and blood collection.

Within the scope of the 2015 ICC activities of the hospital; healthcare personnel were asked to undergo serologic screening tests for HBV and hepatitis $C$ virus ( $\mathrm{HCV}$ ), with the cost slated to be met via the hospital budget. These tests were based on volunteering, and written consents were received from the staff concerning whether to undergo these tests. According to the screening test outcomes, HBVsensitive personnel were administered three doses of the HBV vaccine for free in accordance with the schedule for zero, the first and the sixth months, and antibody responses were closely monitored.

In addition, necessary announcements were made for the 2015-2016-period SFV, which the Ministry of Health supplied for free for the vaccination of the hospital staff.

Personnel who rejected undergoing the screening tests and SVF asked the reasons for this face to face. Participants' age, gender, occupation, department of work, HBV serology outcomes, screening test and reasons for not desiring vaccination with SFV were recorded.

Whereas the staff with completely accessible data who completed HBV vaccination and gave consent were included in the study, personnel still undergoing vaccination, those with inaccessible data or those unwilling to share their data were excluded.

Approval was received from local ethics committee to use these activities of the ICC for scientific purposes (21.06.2016/8000-39-16). 


\section{Statistical analysis}

Data of this study were transferred to SPSS IBM 22.0 (SPSS, Inc., Chicago, IL) statistical software and analyzed using this program. The distribution of the data was evaluated with the Kolmogorov-Smirnov test. Descriptive findings of the counted data are given in the distribution of the frequency and percentage, whereas non-normally distributed data are expressed as a median (minimum-maximum). A $p<0.05$ level was considered statistically significant.

\section{RESULTS}

The ICC could reach $253(84.3 \%)$ of the personnel working in our hospital. The median age of the personnel was found to be 30 (21-61) years. Of the participants, $137(54.2 \%)$ were women, and 116 (45.8\%) were men. The study included 47 (18.6\%) physicians, $97(38.3 \%)$ nurses, $15(5.9 \%)$ nursing staff, $6(2,4 \%)$ data preparation operators, $47(18.6 \%)$ technicians, $36(14.2 \%)$ administrative personnel and 5 (2\%) other healthcare personnel (pharmacists, psychologists, dieticians). Of these personnel, 134 (53\%) were working in the polyclinics, $24(9.5 \%)$ in clinics, 15 (5.9\%) in the operating room, 44 (17.4\%) in administrative units, $28(11.1 \%)$ in the laboratory and $8(3.2 \%)$ in the other departments.

A total of 198 (78.3\%) staff underwent the investigations asked. Of the patients screened, 35 (17.7\%) of the participants were found to be HBV sensitive, 148 (74.7\%) vaccinated and 15 (7.6\%) natural immunized. The median value was found to be 787.62 $\mathrm{IU} / \mathrm{mL}$ (10.86-1000 IU/mL) in the participants with positive hepatitis $B$ surface antibody identified. The HBV vaccine was administered in $32(91.4 \%)$ of the sensitive personnel. In the control, after three doses of the vaccine, response to vaccination occurred in all of them. Anti-HCV-negative was found in all of the personnel who underwent screening investigations. Among the $55(21.7 \%)$ personnel who did not accept being screened, the reasons for rejecting investigations were found to be 'having no time' in
26 (47.3\%), being vaccinated for HBV in 20 (36.4\%), being natural immunized in four $(7.3 \%)$, recently undergoing investigations in three $(5.5 \%)$, being afraid of injection in one $(1.8 \%)$ and not wanting to be vaccinated for HBV in one (1.8\%) patient.

Thirty-six (14.2\%) personnel underwent SFV. One of $217(85.8 \%)$ persons who rejected being vaccinated for SFV vaccination reported the reason as 'allergic reaction', while the remaining personnel reported the reason as 'having no time'.

\section{DISCUSSION}

It was observed in our hospital in the 2013-1014 period that $13.7 \%$ of the personnel were vaccinated with SFV, $17.4 \%$ of the personnel were unvaccinated for HBV in 2014 and the need existed for the education and motivation of the staff about immunization (8). Meanwhile, we observed in the present study that the majority of the personnel were screened for $\mathrm{HBV}$ and $\mathrm{HCV}$, and the rates of SFV and HBV vaccinations were $14.2 \%$ and $13.8 \%$, respectively. It was found that the rates of SFV vaccination slightly increased, while HBV vaccination targets were substantially achieved with the necessary personal education and motivating activities performed.

$\mathrm{HBV}$ is the most preferred vaccine in our country among the vaccines that healthcare personnel have to administer (9). In a tertiary healthcare center, $81.8 \%$ of the personnel were found to be anti-HBs positive and $16.5 \%$ HBV sensitive (10). This vaccine is not easily accessible, which is the most important reason for healthcare personnel not to be vaccinated for HBV. However, a portion of personnel are not aware of this disease or think it is not important (11). Given that healthcare personnel in our country have free vaccination opportunities, we believe that the rates of HBV vaccination could be increased via raising awareness through screening tests as in our hospital.

Healthcare personnel are known to play a role in hospital-borne influenza. Two major factors affecting 
the transmission of influenza infections by healthcare staff are the personnel's continuing to work while having the disease and the display of a few or no symptoms despite the spread of the virus (12). In a randomized study performed among healthcare personnel, the effectiveness of the vaccine was demonstrated in $88 \%$ of the vaccinated personnel for influenza A and $89 \%$ for influenza B (13).

In a previous study conducted in our hospital, the most common reasons for rejecting the undergoing of SFV included not believing its benefits, thinking that people who have previously undergone influenza are not vaccinated, being afraid of the side effects, believing that immunization due to previous vaccination continues and thinking it is harmful. Meanwhile, the most common reason for rejecting the HBV vaccination was found to be 'neglect' (8).

Negative opinions of personnel usually stem from previous vaccination experiences, and they believe they have influenza despite having been vaccinated. In a study that Couto et al. (14) conducted, respiratory symptoms were followed up for four months after vaccination to correct the wrong information about the reliability and effectiveness of SFV. It was determined using molecular methods that $5.3 \%$ of the episodes developed were caused by influenza and $27.9 \%$ by the other respiratory viruses. With an awareness-raising campaign organized in Germany, the rate of immunization with SFV increased to $26 \%$ from $21 \%$ among healthcare personnel (15). The realization of risk factors increased the decision to be vaccinated 2,5-fold (16). Increased awareness led to a significant impact, especially on physicians, increasing the rates of vaccination from $21 \%$ to $31 \%$ (15). Among the personnel who think of themselves as being at risk and undergo vaccination, $89.1 \%$ reported they have had SVF vaccination to protect themselves and $55.2 \%$ to protect their patients (17).

Methods used in awareness-raising works affect the rates of vaccination. It was found that the strongest factor affecting the decision of healthcare personnel to undergo vaccination was the posters related to occupational health (9,55-fold) (18). A review conducted on this topic compared the effectiveness of several educational methods, such as flyers, slide shows, conferences, posters and short video shows, with promoting methods, such as vaccination day, high-priced holiday gifts and vaccination for free. Performing and promoting educational activities together was demonstrated to be the intervention that increased the rates of SVF by the highest percentage (19).

In our hospital, the most common reason for not having screening tests and SFV vaccination was reported to be 'having no time'. In our centre, it might be more effective to assign a 'vaccination day' and 'screening day', to take the vaccines to the areas of work of the personnel for them to receive in their spare time; to prepare an environment for the personnel where they would feel safe and to replace the educational material with more striking and impressive methods. Imposing the use of masks for personnel might be an annoying but effective method.

We think demonstrating the positive effects of problem-directed solutions related to immunization activities would provide a contribution to the literature. The most important limitation of this study was that screening tests and vaccination were not mandatory. Although a majority of the personnel could be reached, we could not determine the serologic statuses of all of the participants.

In conclusion, it was determined in this study that personnel may participate in vaccination with a large proportion if awareness is raised with screening investigations, and educational activities could be effective in increasing the rates of vaccination. We believe it would be useful for every healthcare center to identify the problems specific to itself and to evaluate the success of the solutions used. Further studies are needed in our country to compare the effects of the educational and promoting activities on the rates of vaccination of healthcare personnel. Uncertainty remains regarding the most effective method in our society. 


\section{REFERENCES}

1. Puro V, De Carli G, Cicalini S, Soldani F, Balslev U, Begovac J, et al. European recommendations for the management of healthcare workers occupationally exposed to hepatitis B virus and hepatitis C virus. Eurosurveillance, 2005;10(10):1-9.

2. Anonymous. Genișletilmiș Bağıșıklama Programı Genelgesi. Ankara: T.C. Sağlık Bakanlığı Temel Sağlık hizmetleriGenel Müdürlüğü. 2009: B100TSH0110005. Tarih: 13.03.2009/7941. 2009. http://www.saglik. gov.tr/TR/belge/1-8187/genisletilmis-bagisiklamaprogrami-genelgesi-2009.html, (Accessed: Nov,02, 2016).

3. Dokuzoguz B. Updated vaccine recommendation in health care workers. Ankem, 2014; 28(Ek 2): 199-206.

4. Ertek M, Sevencan F, Kalaycioglu H. Pandemic influenza A (H1N1) vaccination status and factors affecting vaccination: Ankara and Diyarbakir 2009 data from Turkey. Microbiol Bul, 2011; 45(4): $684-$ 96.

5. Savaser S, Canbulat N, Sahin S. Awareness stages of nursing students about influenza A (H1N1) and it's vaccine. J iÜFN Hem, 2011; 19(3): 122-8.

6. Gazmararian JA, Coleman M, Prill M, Hinman $A R$, Ribner BS, Washington ML, et al. Influenza vaccination of health care workers: policies and practices of hospitals in a community setting. Am J Infect Control, 2007; 35(7): 441-7.

7. Launay O, Le Strat Y, Tosini W, Kara L, Quelet S, Lévy $S$, et al. Impact of free on-site vaccine and/ or healthcare workers training on hepatitis B vaccination acceptability in high-risk subjects: a pre-post cluster randomized study. Clin Microbiol Infect, 2014; 20(10): 1033-9.

8. Karacaer Z, Ozturk I, Cicek H, Simsek S, Duran G, Gorenek L. The knowledge, attitudes and behaviors on immunization of healthcare workers. TAF Prev Med Bull, 2015; 14(6): 353.

9. Koruk I, Tekin Koruk S, Tuncer K, Demir C, Kara B, Seyhanoglu AS. The immunization level of healthcare workers against occupational infectious diseases in Şanlıurfa. Klimik, 2014; 27(2): 48-56.
10. Baysal B, Kaya S. Seroprevalance of HBV, HCV and HIV among health care workers in a training and research hospital. Viral Hepatitis J, 2012; 18(3): 94- 7.

11. Chaudhari CN, Bhagat MR, Ashturkar A, Misra RN Hepatitis B immunisation in health care workers. MJAFI, 2009; 65(1): 13-7.

12. Gavazzi G. Influenza vaccination for healthcare workers: from a simple concept to a resistant issue? Aging Clin Exp Res, 2009; 21(3): 216-21.

13. Wilde JA, McMillan JA, Serwint J, Butta J, O’Riordan MA, Steinhoff MC. Effectiveness of influenza vaccine in health care professionals: a randomized trial. J Am Med Assoc, 1999; 281(10): 908-13.

14. Couto CR, Pannuti CS, Paz JP, Fink MCD, Machado $A A$, de Marchi $M$, et al. Fighting misconceptions to improve compliance with influenza vaccination among health care workers: an educational project. PLoS One, 2012; 7(2): 1-6.

15. Leitmeyer K, Buchholz U, Kramer M, Schenkel K, Stahlhut $\mathrm{H}$, Köllstadt $M$, et al. Influenza vaccination in German health care workers: effects and findings after two rounds of a nationwide awareness campaign. Vaccine, 2006; 24 (47-48): 7003-8.

16. Esposito S, Bosis S, Pelucchi C, Tremolati E, Sabatini $C$, Semino $M$, et al. Influenza vaccination among healthcare workers in a multidisciplinary University hospital in Italy. BMC Public Health, 2008; 8(422): 1-10.

17. Maltezou HC, Maragos A, Katerelos P, Paisi A, Karageorgou K, Papadimitriou T, et al. Influenza vaccination acceptance among health-care workers: a nationwide survey. Vaccine, 2008; 26:1408-10.

18. Qureshi AM, Hughes NJM, Murphy E, Primrose WR Factors influencing uptake of influenza vaccination among hospital-based health care workers. Occup Med, 2004; 54(3): 197-201.

19. Schmidt S, Saulle R, Di Thiene D, Boccia A, La Torre G. Do the quality of the trials and the year of publication affect the efficacy of intervention to improve seasonal influenza vaccination among healthcare workers? results of a systematic review. Hum Vaccines Immunother, 2013; 9(2): 1-13. 